DOI: 10.17951/lrp.2020.39.1.269-282

\author{
WIESŁAW ŻARDECKI \\ Uniwersytet Marii Curie-Skłodowskiej w Lublinie \\ ORCID - 0000-0002-3856-4464
}

\title{
GŁÓWNE KIERUNKI ROZWOJU ANIMACJI KULTURY. OD ANIMACJI SPOŁECZNEJ DO OSOBOWEJ
}

\begin{abstract}
Streszczenie: Niniejszy artykuł przedstawia ogólny zarys przemian animacji kultury, ogólną charakterystykę kierunków jej rozwoju w poszczególnych okresach, na tle przeobrażeń społecznych, politycznych, kulturowych, edukacyjnych. Na szczególną, cywilizacyjno-społeczną i filozoficzną, genezę animacji wskazują konstytutywne właściwości nowoczesnych społeczeństw przemysłowych i człowieka ery industrialnej. Zasadniczą część artykułu poświęcono odtworzeniu drogi rozwoju animacji na tle przemian kulturowych oraz przedstawieniu wielopłaszczyznowości pojmowania i uprawiania animacji kultury ostatnich kilkudziesięciu lat. $\mathrm{Na}$ tym tle zarysowano personalistyczną koncepcję animacji kultury, zorientowaną na tworzenie warunków sprzyjających rozwojowi osobowemu człowieka czy też samorealizacji osoby ludzkiej. W świetle badań kierunek najważniejszych przemian animacji wiedzie od nastawienia na kontestację kultury elitarnej do wielości jej współczesnych paradygmatów, w większości zbieżnych w ujęciach i głównych intencjach. Prezentowany tekst ma na celu wstępne uporządkowanie tytułowego zagadnienia lub raczej zebranie materiału do działań porządkujących informacje o zjawiskach tworzących historię animacji.
\end{abstract}

Słowa kluczowe: animacja kultury, animator kultury, animacja społeczna, osobowa koncepcja animacji kultury

\section{WPROWADZENIE}

Historia animacji kultury jest dobrym przykładem koncepcji formułowanych nie tak często $\mathrm{w}$ nauce, które $\mathrm{z}$ chwilą pojawienia się stopniowo rozrastają się, zdobywając coraz szersze kręgi zwolenników, bogacą się w treści i wreszcie stają się organizatorami życia kulturalnego w skali niepodejrzewanej w chwili ich pojawienia się. Żadna koncepcja rozwoju kultury nie miała dotąd takiego rozgłosu 
i zasięgu jak animacja kultury/społeczno-kulturalna, która pojawiła się w latach 60. ubiegłego wieku w opracowaniach francuskich, później belgijskich i kanadyjskich, a następnie w latach 70. i 80. znalazła odbicie w literaturze naukowej angielskojęzycznej i niemieckojęzycznej. Animacja nie jest już dziś tylko koncepcją interesującą entuzjastów, praktyków i badaczy specjalistów, lecz jest to idea uniwersalna i zbiorcza, która dotyka niemal wszystkich dziedzin życia współczesnych ludzi, funkcjonuje w światowych inicjatywach organizacji międzynarodowych uwydatniających kulturowy wymiar rozwoju.

Aczkolwiek pojęcie animacji upowszechniło się przez ostatnie dekady, to jego zakres jest nadal dość trudno uchwytny, różnie interpretowany i bardzo pojemny treściowo; posługujemy się nim w wielu znaczeniach, zarówno w języku potocznym, jak i publicystycznym oraz w literaturze naukowej, w sposób wąski i szeroki. Przez animację kultury będziemy rozumieć system działań pobudzających poszczególne jednostki i zbiorowości społeczne do aktywnego uczestnictwa w przyswajaniu i tworzeniu kultury na podłożu akceptowalnych i wyznawanych wartości, w wyniku uruchomienia ich własnych możliwości twórczych, często ukrytych i nieuświadomionych.

Zasadniczym celem prezentowanego tekstu jest oszczędna i z konieczności skrótowa prezentacja wiodących kierunków rozwoju animacji kultury (rozwój kultury ma zwykle wiele dróg), tj. wyróżnienie i określenie idei i założeń animacji kultury oraz faktów i doświadczeń kształtujących jej historię. Wyczerpująca prezentacja zagadnienia wymagałaby przywołania wielu koncepcji filozoficznych, socjologicznych, psychologicznych, kulturoznawczych, do których animacja nawiązywała w długim procesie rozwoju owocującym ustaleniami coraz bardziej wnikliwymi i uwzględniającymi coraz to szerszy zakres problemów oraz złożoność warunków, $\mathrm{w}$ jakich przebiega. Przemiany animacji to problematyka równie pociągająca, co ryzykowna, wymagająca wszechstronnej interpretacji, jednak jej ważność wydaje się intuicyjnie oczywista: warunkiem rozumienia trudnych zagadnień animacji jest znajomość tła historycznego, wiedza o dominujących tendencjach, samowiedza teoretyczna animacji kultury. Warto przyjrzeć się tej drodze rozwoju animacji, prześledzić dokonujące się przeobrażenia i zastanowić się nad etapami tych zmian, na tle przemian politycznych, społecznych, kulturowych, również po to, aby lepiej rozumiejąc współczesne koncepcje animacji, realnie ocenić jej perspektywy. Mimo licznych publikacji wiedza o animacji w naszym kraju jest skromna, niepełna, a częściowo przestarzała; tylko niektóre z publikacji polskich autorów opierają się na badaniach empirycznych; zdecydowana większość odwołuje się do literatury obcojęzycznej, przede wszystkim francuskiej, a wiele z nich ma charakter metodyczny. W wymiarze teoretycznym animacja kultury/społeczno-kulturalna w Polsce „nie doczekała się zasadniczego opracowania koncepcyjnego [...], w wymiarze prak- 
tycznym także nie odniosła jak na razie oczekiwanego sukcesu" (Cyboran 2018, s. 10); również „badania nad animacją kultury podejmowane są w naszym kraju niezmiernie rzadko i wycinkowo" (Kubinowski 2018, s. 143). Złożoność procesów animacyjnych i interdyscyplinarny charakter problemów, jakie ma rozwiązywać animacja kultury, rodzą potrzebę rozwijania nie tylko interdyscyplinarnej teorii animacji, budowanej twierdzeniami wielu dyscyplin naukowych (m.in. psychologii humanistycznej, pedagogiki niedyrektywnej, socjologii małych grup), ale i teorii animacji jako odrębnej interdyscyplinarnej dziedziny wiedzy.

\section{ROZWAŻANIA NAD GENEZĄ ANIMACJI KULTURY}

Uważa się, że animacja kultury/społeczno-kulturalna ma swoje źródła w najodleglejszych koncepcjach pedagogicznych, które odwołują się do kreatywnych i wyzwalających wartości kultury oraz łączą w swoich intencjach dyrektywę rozwoju człowieka $\mathrm{z}$ jednoczesnym poszukiwaniem tożsamości grup i zbiorowości (Gajda 2001, s. 12-16). Już od początku animacji pojawiły się bowiem kolejno, w niewielkich odstępach czasu, dwa pozornie rozbieżne nurty działań animacyjnych, które łączył wspólny punkt wyjścia (cel, motyw): aktywizowanie kreatywności jednostek, grup społecznych, małych środowisk i lokalnych społeczności w imię budowania wspólnoty ludzkiej i kształtowania tożsamości kulturowej. Jeden sięgający do idei pedagogiki społecznej i socjologii wychowania (koncepcja wyzwalania utajonych sił społecznych i możliwości kreacji środowisk lokalnych siłami samego środowiska) i drugi nurt, sięgający do idei pedagogiki kultury i edukacji kulturalnej (koncepcja pobudzania życia duchowego jednostki ludzkiej i pogłębiania osobowej tożsamości). Przy czym w animacji o rodowodzie pedagogiki społecznej eksponuje się w pobudzaniu i ożywianiu rolę społeczności lokalnej lub regionalnej, a więc grupy ludzi żyjącej na określonej przestrzeni oraz stymulowanie zachodzących w niej przemian opartych na akceptowanych i uznawanych wartościach, utrwalających tożsamość tejże grupy w szerszej społeczności czy całym społeczeństwie. Natomiast $\mathrm{w}$ animacji o rodowodzie pedagogiki kultury akcent pada nie tyle na całą grupę, środowisko czy lokalną społeczność, ile na stymulowanie naturalnych możliwości kreacyjnych ukrytych w ludzkiej jednostce, indywiduum, osobowości, tj. na twórcze impulsy, wyzwolenie duchowe, przeżycia wewnętrzne.

Dopiero później wyłonił się trzeci nurt myślenia o źródłach animacji nawiązujący do postmodernizmu albo inaczej - jak zauważa Józef Kargul - „koncepcja animacji była impulsem postmodernistycznego myślenia o kulturze", które stało się czymś w rodzaju samoświadomości współczesnej kultury, współczesnej praktyki artystycznej (Kargul 1996, s. 103; Kargul 2012, s. 160). W myśl tego stanowiska 
teoria animacji przejęła cechy charakterystyczne dla postmodernizmu: umasowienie kultury, zacieranie granicy między kulturą elitarną a popularną, przewartościowanie (wartości wyższe wypierane są przez wartości niższe - instrumentalne); dowartościowywanie indywidualnych podmiotów życia społecznego; promocja kultury oddolnie tworzonej; stawianie na wielość, różnorodność itd. Oczywiście sytuację w obszarze animacji kultury wyznaczały też inne zjawiska, takie jak zanik kultur tradycyjnych pod wpływem rewolucji przemysłowej, słabnięcie społecznego prestiżu uniwersalnych wartości sztuki wysokiej, ekspansywność kultury masowej pozbawionej intencji sublimacyjnych, sprowadzanie sztuki do poziomu towaru poddanego manipulacjom rynkowym.

Ponieważ przedmiot animacji był zawsze słabo wyodrębniony, niejednoznaczny i niedookreślony (nie była nim sama kultura czy życie społeczne, ale pożądana aktywność ludzka w życiu społeczno-kulturalnym), dlatego też trudno precyzyjnie określić pojawienie się tego zjawiska w różnych obszarach życia i działalności człowieka. Cofając się do nieodległej przeszłości, uświadamiamy sobie, w jakim stopniu tradycyjne życie na wsi oraz w robotniczych dzielnicach ośrodków przemysłowych, a także małych rolniczo-przemysłowych miasteczkach, było wspólnotowe i oparte na pewnych zasadach oraz relacjach grupowych, odnoszących się do wykonywania tej samej pracy, ale również spędzania czasu wolnego. Rynki, studnie na wsi, gospody przydrożne, place przed kościołem oraz domy rodzin wielopokoleniowych były naturalnymi miejscami wspólnych spotkań, w których kształtowały się tradycyjne formy życia wspólnotowego, a wraz z nimi trwałe związki między ludźmi oraz układy odniesienia określające tożsamość kulturową swoich członków. Wydaje się, że w każdej miejscowości można było znaleźć choć kilka osób nieobojętnych na sprawy własnej zbiorowości lokalnej czy miejscowości, a więc osób o bardziej rozwiniętym patriotyzmie lokalnym, które poprzez odpowiednio postawione cele i właściwe działania ożywiały życie tych społeczności i integrowały je na nowo wokół problemów do rozwiązania. Można zatem przyjąć, że zawsze występowała animacja pierwotna, spontaniczna, nieformalna (niezamknięta w struktury, programy czy instytucje), podejmowana przez osoby, które dobrowolnie obok swojego właściwego zajęcia oraz ze względu na posiadanie pewnych umiejętności i cech osobowych, ustawiały się w roli naturalnych przywódców grupy, liderów środowiskowych czy inicjatorów określonych wydarzeń zbiorowych.

Jak podaje Małgorzata Kopczyńska, narodziny animacji jako wieloaspektowego zjawiska miało miejsce we Francji w latach 40. ubiegłego wieku i było efektem splotu rozmaitych prądów, inicjatyw i aktywności: środowiskowej, wyznaniowej, związków zawodowych, stowarzyszeń kulturalnych i organizacji młodzieżowych oraz licznych ruchów ideowych i edukacyjnych; m.in. ruchu oświaty ludowej (Kopczyńska 1993, s. 52). Głównym celem było pobudzanie aktywności społecznej, 
autentycznej samorządnej przedsiębiorczości, realnej współodpowiedzialności za wspólne dobro oraz kształtowanie ludzi, którzy będą wnosić w życie publiczne, instytucje i grupy sformalizowane wiarę w skuteczność osobistej inicjatywy, w możliwość realizacji rzeczywistej samorządności w różnych sferach życia. Kierowano się przekonaniem, że jeśli poprawa warunków życia ma mieć charakter trwały, muszą jej towarzyszyć pewne zmiany społeczne oraz zmiany postaw ludzi, co wymaga wciągnięcia do współpracy przede wszystkim samych zainteresowanych ludzi, którzy powinni współdziałać w układaniu programu naprawy i w jego realizacji.

Rozwój animacji na początku lat 60. XX wieku w kręgu państw zachodnich był związany z charakterystycznymi dla tego czasu przemianami kulturowymi i cywilizacyjno-technicznymi, dyktowanymi głównie wewnętrznymi uwarunkowaniami, które obok wielu niewątpliwych udogodnień życia, niosły ze sobą niebezpieczne zagrożenia dla humanistycznych aspektów rozwoju człowieka i podstawowych wspólnot ludzkich. Dojrzewający w tym czasie typ społeczeństwa przemysłowego rozbił tradycyjne formy i struktury życia społecznego, a tym samym zniszczył sferę wartości zbiorowych opartych na pewnych doświadczeniach wspólnotowych oraz pozbawił jednostkę poczucia tożsamości wynikającej z uczestnictwa w psychicznej jedności grupy społecznej, małego środowiska czy lokalnej społeczności. W miejsce zbiorowości złączonej wspólnotą wartości i wzorów kultury oraz stabilnym poglądem na życie, pojawiło się bezosobowe społeczeństwo masowe podlegające mechanizmom kierująco-regulującym; w miejsce jednostki świadomie przeżywającej swoje uczestnictwo w życiu zbiorowym - indywiduum połączone ze zbiorowością na zasadzie relacji „urzeczowionych” i ściśle określonych ról. Trafnie ujęła genezę animacji Małgorzata Kopczyńska, podkreślając, że rozwój, rolę i miejsce animacji społeczno-kulturalnej oraz powstanie zawodu animatora warunkują problemy „rozbitego społeczeństwa”, w którym nastąpił rozpad tradycyjnych form i struktur życia społecznego oraz związanej z nim „pękniętej kultury”, kultury mozaikowej (Kopczyńska 1993, s. 10-19).

W latach 60. termin „animacja” używany jest coraz częściej, aby ukazać pewien rodzaj bezpośredniego pobudzania (za pomocą metod niedyrektywnych) autentycznej (naturalnej) komunikacji międzyludzkiej oraz wartościowych relacji międzygrupowych (struktur życia społecznego) w miejscu zamieszkania (osiedlu, dzielnicy, mieście czy regionie). Animator w tym procesie był osobą, która z racji pełnionych funkcji poszukuje skutecznych sposobów adaptacji jednostki do zachodzących przemian, kreuje partnerski styl w relacjach interpersonalnych; pomaga człowiekowi w budowaniu własnej tożsamości kulturowej i łączności z drugim człowiekiem oraz ze wspólnotą, która wzbogaca rozwój jednostki. Animacja była zatem pewnym bodźcem dla życia społeczno-kulturalnego mieszkańców określonego sektora, aby zachęcić ich do podjęcia określonych działań, które ułatwią im adaptację 
do zmieniających się warunków życia oraz wzmocnią osłabione więzi społeczne, a także dadzą poczucie przynależności do społeczeństwa podlegającego ewolucji. Animacja ewoluowała w kierunku rozbudzania aspiracji środowisk lokalnych, zachęcania ich do rozwiązywania bolączek życia własnymi siłami oraz przełamywania bariery własnego rozwoju; podstawową jednak zasadą tych działań była oddolność inicjatyw, nieingerowanie w nie podmiotów zewnętrznych. W najbardziej ogólnym znaczeniu animacja miała stanowić ważny instrument urzeczywistniania podstawowych wartości społeczeństwa obywatelskiego, w którym będą istniały większe możliwości rozwoju jednostek i środowisk otwartych na zmiany, zdolnych do tworzenia własnej przyszłości. Wspólny rozwój społeczności lokalnych był traktowany jako czynnik integrujący całą aktywność zbiorowości, nie tyle w sensie ekonomicznym, co kulturowym, jakości życia i awansu jednostki poprzez edukację permanentną i uczestnictwo $\mathrm{w}$ demokracji bezpośredniej oraz dobre wykorzystanie środowiska życia.

\section{RUCH ANIMACJI KULTURY: ZAŁOŻENIA I ROZWÓJ}

Istotne dla zrozumienia klasycznej animacji francuskiej jest to, że wyrastała ona w czasach głębokiego kryzysu politycznego końca lat 60., poczucia bezsensowności cywilizacji konsumpcyjnej, uświadomienia anachronizmów w strukturach społecznych i obciążeń wynikających z prowadzenia zbrojeń oraz wydarzeń ujawniających na masową skalę dążenia emancypacyjne i podmiotowe ludzi (Wojnar 2008, s. 87). Ale jednocześnie w czasach kształtowania się nowej wrażliwości w związku z elektronicznymi środkami rozpowszechniania kultury i zmianami zachodzącymi w kulturze artystycznej, wygasania wielkich kierunków XX wieku i kształtowania się nowych prądów $w$ sztuce, $\mathrm{z}$ ich starciem $\mathrm{z}$ tradycją, przemianami, jakie spowodowały oraz widokami, jakie zarysowały się dzięki nim. Właśnie pod koniec lat 60. ruch animacji stanął przed istotnym dylematem: być instrumentem, narzędziem na usługach narzuconej kultury elitarnej czy też środkiem, sposobem wyrażania kultury „wznoszącej się”, „oddolnie tworzonej”, mocą dynamiki grup i zbiorowości, pobudzania ich możliwości kreacyjnych (Besnard 1988, s. 359).

Dla animacji za datę przełomową przyjmuje się 1968 rok - początek wielkich kontestacji młodego pokolenia wobec tradycyjnego systemu wartości klas średnich, który głosząc pochwałę działań ekonomicznych i racjonalnego stosunku do rzeczywistości, ogarnął do tego stopnia społeczeństwo, że skutecznie zagroził innym wartościom i potrzebom człowieka. Opozycja wobec tradycjonalizmu dała o sobie znać przede wszystkim w kręgu francuskiej młodzieży, szeroko popartej przez starszą młodzież licealną, która na czoło wysunęła wartości najtrwalsze 
i najcenniejsze, jak szacunek dla życia, życzliwość dla ludzi, podziw dla wiedzy, świadczenie o prawdzie, wspólnota z człowiekiem, zasady etyczne w życiu. Napięcia i wstrząsy tego okresu odbiły się głośnym echem w sferze życia kulturalnego: domagano się „wysadzenia” instytucjonalnych ram kultury oficjalnej, wyzwolenia kultury w przestrzeni życia codziennego, wolności wyrażania własnych doświadczeń i manifestowania własnej inności, „śmierci sztuki” w jej tradycyjnym kształcie, postawienia kultury wobec zasadniczych problemów współczesności (aby sztuka nie była już „sztuką piękną”, a stanowiła podstawę „sztuki życia”). Sformułowane wówczas wśród młodych kontestatorów hasła, jak: „otwieranie granic kultury”, „kultura dla wszystkich”, „władza dla wyobraźni”, „każda jednostka jest artystą, każdy człowiek jest twórcą”, ,,sztuka? - tak, ale sztuka życia”, „zmieniajmy świat, zaczynając od siebie" - wyrażały nastroje społeczne i były apelem do ludzkiej postawy twórczej oraz wskazywały na wybór strategii działania (Rewolucje 1968, s. 191-223).

Animacja kultury wyrastała z opozycji do kanonizowanej „kultury elitarnej” (wysokiej, artystycznej, wartościowej), tzn. zawierającej „wielkie”, „prawdziwe”, „niezniszczalne” wartości wytworzonej w odległej przeszłości i należące do skarbca kultury narodowej i kultury ogólnoludzkiej, zarezerwowanej dla uprzywilejowanej (intelektualnie lub ekonomicznie) mniejszości; kultury wymagającej kompetencji i postawy estetycznej. Przeciwstawiała się wartościującemu podziałowi na tych, którzy strzegą sensu wartości, uznanych za ogniskowe i zobowiązujące oraz przywiązanych do tych właśnie wartości, a także tych, których do „kulturowej konsumpcji” należy skłonić i którym wartości te należy udostępnić, a często nawet narzucić odpowiednie formy ich przyswajania. Krytykowała też tradycyjną działalność kulturalną podporządkowującą uczestnika aksjologicznym celom, na których kształt nie ma on w zasadzie wpływu, narzucającym mu odgórnie wartości wspólnego zasobu kultury (wzorów, kryteriów, ocen) jako jedynie słusznych, przeznaczonych do konsekwentnej realizacji, wyłączny drogowskaz życiowy. Zakwestionowała również traktowanie sztuki jako zamkniętej dziedziny kultury, sfery izolowanej od rzeczywistości i życia społecznego, przechowywanej w specjalnie do tego celu przeznaczonych instytucjach; wprawdzie sztuka ta w różny sposób oddziaływała na ludzi, lecz sama nie podlegała odbiorcom. Podsumowując, sprzeciwiała się modernistycznym koncepcjom upowszechniania kultury, mającym charakter odgórny, instytucjonalny i formalny, opierającym się na specjalnie opracowanych programach, skatalogowanych celach i oczekiwaniach realizacji przyjętych dyrektyw, sprowadzającym odbiorców do roli niesamodzielnych obiektów oddziaływań zewnętrznych.

Aczkolwiek formułowana w opozycji do modernistycznej koncepcji kultury animacja była równocześnie programem pozytywnym, oryginalnym, dynamicznym, w którym mieściła się określona wizja budowy autentycznej kultury mocą dynamiki grup i zbiorowości w przestrzeni ich życia oraz poszerzania życia kultu- 
ralnego o problemy życia codziennego. Z przyjętych założeń wynikał sens działań animacyjnych jako rozległych, oddalonych, nieformalnych inicjatyw społecznych i kulturalnych jednostek i grup zmieniających, ulepszających warunki życia środowisk lokalnych, w znaczeniu zdecentralizowanych przekształceń grupowych, inspirowanych przez animatora, posługującego się technikami pobudzającymi wyobraźnię, wrażliwość, kreatywność. Działania animacyjne odwoływały się do wartości istniejących od dawna w kulturze lokalnej czy regionalnej, ale zapomnianych, zaniedbanych lub zagrożonych, albo do wartości nowych, które trzeba dopiero formułować i poszukiwać najlepszych dróg ich realizacji na bazie sił i zdolności środowiska, jego własnej kreatywności.

W latach 70. zakres działalności animacyjnej wyraźnie się poszerza w związku z dążeniami emancypacyjnymi i podmiotowymi lokalnych społeczności, małych środowisk, grup społecznych, także na obszarze szeroko pojętej kultury, rozciągającej się na wszystkie dziedziny życia społecznego, od twórczości artystycznej i literackiej, po życie codzienne (szerokie rozumienie kultury zaczerpnięte $\mathrm{z}$ antropologii kulturowej). Animacja tego okresu charakteryzowała się wielością dróg rozwoju, niejednoznacznością oraz pewnym rodzajem praktyczności (użyteczności) zewnętrznej; animacja służyła realizacji wciąż nowych zadań w szybko zmieniającej się rzeczywistości: politycznej, społecznej, kulturowej, edukacyjnej, ekonomicznej, sprzyjających wzrostowi gospodarczemu. Na przykład animacja miała być instrumentem obiegu kultury tworzonej oddolnie, ale też miała ośmielać grupy mniejszościowe do wyrażenia swojego punktu widzenia, wzmacniać autentyczne uczestnictwo obywateli w życiu publicznym, przenosić energię konfliktu społecznego ku zadaniom zbiorowym, prowadzić do postępu w różnych sferach ludzkiego życia, zawsze wprowadzając impulsy aktywizujące to życie i zachęcające ludzi do działania. $Z$ biegiem czasu animacja staje się zjawiskiem coraz powszechniejszym, obejmuje niemal wszystkie dziedziny ludzkiej działalności, „od handlu począwszy a na rozrywce kończąc" (określenie Jana Żebrowskiego 1987, s. 23); w dodatku poszczególne ośrodki animacji skupiały się często na jednej wybranej dziedzinie działalności, a potem poszerzały zainteresowania lub przesuwały się ku innej dziedzinie. Instytucjonalizacja animacji odbywa się w związku z rozwijającymi się wielkimi prądami edukacyjnymi tych czasów, przede wszystkim edukacją permanentną, ustawiczną, której przełomowe znaczenie najwcześniej dostrzeżono we Francji i analizowano w licznych studiach jej dobrodziejstwa dla całego systemu kultury i edukacji społeczeństwa.

Punktem wyjścia instytucjonalizacji animacji były rzeczywiste potrzeby społeczne, chęć ułatwienia realizacji tych potrzeb. Z czasem struktury instytucjonalne animacji rozrastają się coraz bardziej i w pewnym momencie zaczynają mieć własne potrzeby, które stają się przeszkodą w realizacji podstawowych zadań. Tym 
sposobem animacja stała się zaprzeczeniem samej siebie, przeciwieństwem ruchu kontestatorów kultury elitarnej i bojowników tzw. twórczości oddolnej, tworzonej lokalnie, który ją zrodził; co więcej kontrolę nad nią przejęła administracja państwowa, która doprowadziła wkrótce do kodyfikacji zawodu animatora kultury (społeczno-kulturalnego). Postępująca profesjonalizacja i upaństwowienie oraz centralizacja animacji pozbawiają ją swoistości i specyfiki na rzecz instytucji, które nad nią zapanowały, w interesie których napędzono sztuczną koniunkturę podtrzymującą wrażenie żywotności, podczas gdy w istocie pogłębiały się zjawiska degradacji jej pierwotnych idei i założeń.

\section{NOWE TRENDY: OSOBOWA KONCEPCJA ANIMACJI KULTURY}

W latach 80. animatorzy nadal wiele mówią o wspólnej pracy grupowej jako podstawie relacji międzyludzkich i międzykulturowych, ale jakby już wyczerpali własną inwencję twórczą i nastawiają się na pracę warsztatową, techniczną, zamkniętą, „wewnętrzną", skierowaną na autokreację, autorefleksję, samokontrolę, samorealizację. Są to „warsztaty twórcze”, „treningi artystyczne”, „wspólne staże” itp., zatem oznaczają kierunek działania coraz bardziej zamknięty, skierowany na procesy dokonujące się w świadomości pojedynczego człowieka, sprzyjający poszukiwaniom sposobów dotarcia do samego siebie oraz wyższej jakości życia osobowego. W refleksji naukowej na temat animacji wprawdzie nadal eksponowane są kwestie „kultury grupy”, „wartości zbiorowych”, „stosunków międzyludzkich”, ale na pierwsze miejsce zaczyna się wysuwać osoba ludzka i to wszystko, co służy jej dojrzewaniu i rozwojowi duchowo-moralnemu. Widoczny wpływ na przemianę myślenia i działania animacyjnego mają prace orientacji personalistycznej, w których kultura pojmowana jest jako uczłowieczenie rzeczywistości czy jako personalizacja człowieka, tzn. traktowana jest jako sposób istnienia człowieka, droga samorealizacji osoby ludzkiej (Krąpiec 2008). Odwoływano się przede wszystkim do ustaleń Emanuela Mouriera (wartość absolutna osoby ludzkiej tak w kontekście społecznym, jak i kosmicznym), Jacques’a Maritaina (pragnienie wolności duchowej jako jednej z najgłębszych aspiracji osoby ludzkiej), a także do filozoficznej myśli chrześcijańskiej (bezwzględna afirmacja kategorycznego imperatywu miłości osoby dla niej samej) oraz do reprezentujących różne ukierunkowania egzystencjalistów (człowiek powinien zawsze wychodzić poza własne czy narzucone ograniczenia) (Adamski 2005).

Animacja personalistyczna kładąc nacisk na wiecznie twórczą naturę aktywności duchowej osoby ludzkiej (każda osoba jest jedynym źródłem swojej aktywności), jest ukierunkowana na wydobywanie, odkrywanie, odsłanianie czy ujawnianie nieuświadomionych wymiarów „ja” osobowego uczestnika działań animacyjnych. 
Sensem animacji jest - najogólniej - służenie dobru człowieka zarówno jako w wymiarze indywidualnym, jak i wspólnotowym; celem jest rozwój człowieka rozumiany jako proces stawania się integralną osobą ludzką, którego istotą jest własny wysiłek, zmaganie się ze sobą, uwalnianie się od determinant tak zewnętrznych, jak i wewnętrznych, od własnej reaktywności. Aktywność animowanego w tym procesie skierowana jest jakby przeciwko trzem „przeciwnikom” równocześnie: samemu sobie, własnym słabościom, zahamowaniom, ograniczeniom, niewiedzy o posiadanych uzdolnieniach; przeciwko innym ludziom, względem których pragnie on określić własne możliwości oraz przeciwko rzeczywistości obiektywnej, krępującej animowanego założoną nieuchronnością jej praw. Tak rozumiana animacja staje się działalnością „wyzwalającą i uniezależniającą”; odznacza ją to, co porusza, popycha człowieka w kierunku odnalezienia duchowych wymiaru swojego istnienia czy też dążenia istoty ludzkiej do ustawicznego doskonalenia się w swym istnieniu. Animator zaś w tym procesie jest osobą nakierowaną na współdziałanie $\mathrm{z}$ animowanym $\mathrm{w}$ jego dążeniach do ustawicznego doskonalenia się w swym istnieniu osobowym; współdziałanie wyrażające się w życzliwej obecności i trosce, w pomocy i inspiracji, w szacunku dla jego wysiłku wzrostu osobowego, odpowiadającego jego aspiracjom, możliwościom i potrzebom.

Tak ujęta animacja ma być skuteczną formą edukacji wobec standaryzacji i unifikacji kultury, manipulującej osobą ludzką, niszczącej wartości osobowe; wobec komercjalizacji i kosmopolityzacji kultury oficjalnej, coraz mniej wyrażającej i zaspokajającej ludzkie potrzeby, dążenia, odczucia, coraz bardziej - potrzeby producentów, sponsorów, władz. Osobowa koncepcja animacji kultury byłaby reakcją przeciw współczesnym społeczeństwom technologicznym, hedonistycznym i konsumpcyjnym, z charakterystycznym dlań stylem życia cechującym się silną potrzebą posiadania, biernością egzystencji, żądzą przeżycia przyjemności. Coraz bardziej oczywiste jest, że konsumpcyjny sposób widzenia świata prowadzi do zawężenia wolności jednostki, wewnętrznego zubożenia, atrofii wrażliwości emocjonalnej, destrukcji systemu wartości etycznych, redukowania człowieka do funkcji cząstkowych, utraty motywacji do bezinteresownych działań społecznych.

Podsumowując, animacja ożywiająca i pobudzająca duchowość immanentnie tkwiącą w osobowości jest zorientowana na tworzenie warunków sprzyjających doskonaleniu osobowemu człowieka - mówiąc językiem personalizmu - pomagających istocie ludzkiej urzeczywistnić w pełni jej człowieczeństwo. Nie trzeba dodawać, że autorowi artykułu ideowo najbliższa jest animacja odnosząca się do sposobu istnienia człowieka jako człowieka, jego bogactwa duchowego, stylu funkcjonowania osobowego, sposobu istnienia w świecie ludzkim, wyrażającego się wyborem określonych wartości, rodzajem wrażliwości, zdolnością autokreacji. 


\section{PODSUMOWANIE}

Główne kierunki rozwoju animacji kultury można w pewnym uproszczeniu scharakteryzować następującymi twierdzeniami. W całokształcie swych założeń animacja była jedną z dróg przezwyciężenia arbitralnego traktowania kultury elitarnej jako jedynego rodzaju manifestacji uniwersalnej godnej upowszechniania oraz biurokratycznej pedagogiki opartej na hierarchicznym stosunku zależności między „nauczycielem a uczniem”, z trudem dającym się godzić z inspiracją do tworzenia. Odwoływała się do nurtów pedagogiki niedyrektywnej, akcentującej autonomię jednostek, grup społecznych, małych środowisk i lokalnych społeczności, ich podmiotowość, przejawiającą się poczuciem wolności wyboru, poczuciem sprawczości, odpowiedzialności za swoje działania oraz równoprawnych, partnerskich kontaktów międzyludzkich. Stanowiła zatem ważny składnik pedagogiki nastawionej nie tyle na pouczanie człowieka, przekazywanie „zamkniętej” wiedzy czy wzorów do naśladowania, ile na „otwieranie człowieka”, na inspirowanie jego sił duchowych, stymulowanie naturalnych możliwości twórczych, aktualizowanie potencjału zdolności rozwojowych.

Jednocześnie animacja wyrażała intencję wyzwolenia się z kultury wzniosłej i elitarnej, hieratycznej i monumentalnej, odświętnej i historycznej, wyizolowanej i muzealnej (jako zbioru eksponatów do oglądania), oderwanej od problemów człowieka i zasadniczo różniącej się od otaczającej go rzeczywistości przez ponowne powiązanie jej ze zjawiskami życia zbiorowego oraz zwielokrotnienie życia kulturalnego poprzez problemy życia codziennego. Animacja była propozycją „trzeciej kultury” (obok kultury elitarnej i kultury masowej), włączonej w żywe doświadczenie konkretnych ludzi, odwołującej się do wrażliwości, aktywności i wyobraźni, a bazującej na inspiracji, pobudzaniu, stymulacji osobowości dzięki różnego rodzaju przeżyciom i doświadczeniom (Wojnar 2008, s. 47). Istotnym jej przesłaniem było wykazanie, że istnieje możliwość tworzenia kultury poza zinstytucjonalizowanymi strukturami państwowymi, nie za pomocą sztywnych form represyjnych „z góry w dół”, lecz poprzez aktywne uczestnictwo kulturalne, bezpośrednią komunikację międzyludzką, całokształt sposobów porozumiewania się ludzi. W ten sposób nadmiernie zinstytucjonalizowane czy wręcz zbiurokratyzowane życie kulturalne miało zostać zastąpione duchem inwencji, formami niekonwencjonalnymi, spontanicznymi aktami twórczymi, zbiorowymi wytworami twórczej wyobraźni, autentycznym uczestnictwem w tworzeniu nowych form życia wspólnotowego.

Animacja kultury społeczności lokalnych z biegiem lat ewoluuje w kierunku wymiany doświadczeń z wybranymi grupami, które swoją podmiotowość kreują na podstawie różnych dziedzin kultury symbolicznej, różnych wartości, stylów życia, wizji przyszłości; przez zderzenie ze sobą odmiennych tradycji kulturowych 
poszczególnych środowisk następuje ich wzajemne wzbogacanie. Jak się wydaje, większość doświadczeń animacyjnych ostatnich lat wiąże się z pytaniami: jak można w interesie człowieka wykorzystać różnorodność kulturową rozmaitych grup? Jak można osiągnąć równowagę między adaptacją wspólnych norm a akceptacją inności grup żyjących w odmiennych niż nasze warunkach społecznych, organizacyjnych, kulturowych?

Z kolei orientacja osobowa to nowy sposób podejścia do animacji, który przenosi punkt ciężkości z myślenia społecznego na osobowościowy, personalistyczny i który stwarza alternatywne możliwości w walce z przyczynami i objawami alienacji nowoczesnej cywilizacji, w walce o nowy humanistyczny kształt świata i kultury. Zwrot ku wewnętrznym dążeniom człowieka do samorealizacji nie oznacza zamykania się $\mathrm{w}$ ramach świata wewnętrznego czy przeciwstawienia człowieka i świata zewnętrznego, lecz wzmocnienie funkcji wyrażania się poprzez bycie człowieka w związku z innymi ludźmi, wzmocnienie funkcji indywidualności w sferze życia społecznego.

Wyróżnione kierunki animacji kultury dominowały w poszczególnych okresach lub wzajemnie się przeplatały, a przy tym trwały jeszcze w swojej starej postaci koncepcje upowszechniania kultury, czasem ledwie wegetując, czasem olśniewając cennymi inicjatywami, czasem twórczą ideą kulturową. Bez wnikania w uwarunkowania tego stanu rzeczy można spojrzeć na relacje między upowszechnianiem a animacją kultury $\mathrm{w}$ aspekcie różnic i podobieństw w podstawowych założeniach, charakterze celów, formach działania, systemie oddziaływań, oczekiwaniach uczestników, kryteriach oceny itd. Różnic między nimi należy dopatrywać się przede wszystkim w odmiennej koncepcji człowieka i jego rozwoju, leżącej u podstaw twierdzeń omawianych paradygmatów, w innym ujęciu roli animatora i uczestnika działań kulturalnych, w stosowaniu odmiennych metod oddziaływań, w realizacji różnych wzorów uczestnictwa kulturalnego oraz odmiennej organizacji życia kulturalnego itd. Z kolei tym, co łączyło animację i przeciwstawiało upowszechnianiu kultury, było odejście z jawną determinacją od wcześniej obowiązującego modelu kultury gotowych produktów artystycznych (trwałych dokonań twórczych) na rzecz kultury kontaktów międzyludzkich, równoprawnych, partnerskich, do czego przyczyniły się też inne zjawiska.

W animacji ważne stają się nie gotowe wytwory, produkty kultury, lecz wspólna praca nad nimi, sama w sobie pasjonująca i pochłaniająca; nie odbiór przekazów kultury (czyli oglądanie, słuchanie), lecz mediacja ludzkich kontaktów poprzez kulturę i akcje paraartystyczne; nie określone kryteria estetyczne, lecz wartości etyczne, mikrospołeczne rozwijane $\mathrm{w}$ działaniach animacyjnych; nie utrwalone schematy działań kulturalnych, lecz oddolne inicjatywy, niezależne działania spontaniczne. To właśnie w znacznym stopniu za sprawą animacji tworzy się kultura 
bardziej naturalna, aktywna, żywotna, która zrywa z praktyką dawnej kultury, $\mathrm{z}$ jej racjonalizmem, formalizmem, indywidualistycznym nastawieniem; uczy współpracy i solidarności, pobudza do działania i twórczości, umacnia związek kultury z życiem, staje się ogniskiem samego życia.

Wyróżnione kierunki animacji funkcjonują w szerokich kontekstach społecznych, politycznych i kulturowych uwarunkowań, wiążą się z określonymi koncepcjami społeczeństwa, kultury i edukacji, a jednocześnie ze współczesnymi zjawiskami i problemami (kryzys tożsamości historyczno-kuturowej, zubożenie kodów komunikacyjnych), a także z ideą postępu i rozwoju, którego człowiek jest celem i wartością. Sama idea animacji nie traci swej aktualności. Jakkolwiek epoka największych dokonań zdaje się przechodzić do historii, utrzymuje jednak trwałe miejsce w nurcie współczesnych ruchów kulturowo-edukacyjnych, wzmacniana przez autorytet UNESCO, podkreślającej znaczenie animacji w kształtowaniu społeczeństwa obywatelskiego i sprawnie działającej demokracji oraz podmiotowości jednostek.

\section{LITERATURA}

Adamski F. (red.), 2005, Wychowanie personalistyczne. Kraków, Wydawnictwo WAM. Besnard B., 1988, Problemy animacji społeczno-kulturalnej. W: M. Debesse, G. Mialaret (red.), Rozprawy o wychowaniu, t. 2. Warszawa, Państwowe Wydawnictwo Naukowe. Cyboran B., 2018, Animacja w systemie zależności instytucjonalnych. Kraków, Wydawnictwo Uniwersytetu Jagiellońskiego.

Gajda J., 2001, Dylematy animacji kulturalnej w dobie gwałtownych przemian społecznych i cywilizacyjnych. W: J. Gajda, W. Żardecki (red.), Dylematy animacji kulturalnej. Lublin, Wydawnictwo UMCS.

Kargul J., 1997, Od upowszechniania kultury do animacji kulturalnej. Toruń, Wydawnictwo Adama Marszałka.

Kargul J., 2012, Upowszechnianie, animacja, komercjalizacja kultury. Warszawa, Wydawnictwo Naukowe PWN.

Kopczyńska M., 1993, Animacja społeczno-kultualna. Podstawowe pojęcia i zagadnienia. Warszawa, Centrum Animacji Kulturalnej.

Krąpiec A.M., 2008, Człowiek i kultura. Kraków, Polskie Towarzystwo Tomasza z Akwinu.

Kubinowski D., Lewartowicz U., 2018, Animacja kultury w perspektywie pedagogicznej. Kraków, Wydawnictwo „Impuls”.

Rewolucje, 2008, Praca zbiorowa. Warszawa, Zachęta Narodowa Galeria Sztuki, Agora S.A. 
Wojnar J., 2008, Idee edukacyjne na rozdrożach XX wieku. Warszawa, Wydawnictwo Akademickie Żak.

Żebrowski J., 1987, Zawód i osobowość animatorów kultury: w świetle koncepcji wychowania zintegrowanego. Gdańsk, Wojewódzki Ośrodek Kultury.

\title{
MAJOR PATHS OF DEVELOPMENT IN CULTURAL ANIMATION
} FROM SOCIAL TO PERSONAL ANIMATION

\begin{abstract}
The paper provides an overview of changes in cultural animation and general characteristics of its paths of development during specific periods, in view of the social, political, cultural and educational changes. While determining the unique human and social, as well as philosophical background of animation, the authors referred to premises relating to underlying qualities of modern industrial societies and man of the industrial age. The main body of the paper was devoted to reconstruction of cultural animation developments in view of cultural changes, and to presentation of a multi-faceted theoretical and practical approach to cultural animation over the past few decades. This served as the background for outlining a personalistic concept of cultural animation, focused on creating conditions conducive to personal development and self-fulfilment of humans. In the light of the study, cultural animation has seen the major shift from focus on opposing elite culture to multiplicity of its contemporary paradigms which, to a considerable extent, share the same approaches and main intentions. The paper is intended to methodize the examined issue, or rather to collect the material allowing to correctly classify the phenomena underlying the developments in cultural animation.
\end{abstract}

Keywords: cultural animation, organiser of cultural activities, social animation, personal approach to cultural animation 